\title{
Factors influencing the deterioration of the carapace surface during the moult cycle of Carcinus maenas (Linnaeus, 1758)
}

\author{
Giuliano Greco ${ }^{1,2,3}$, Marco Faimali², John Davenport ${ }^{1}$ \\ ${ }^{1}$ School of Biological, Earth and Environmental Sciences, Enterprise Centre, Distillery Fields, North Mall Campus, \\ University College Cork Cork, Ireland \\ ${ }^{2}$ CNR - ISMAR Via De Marini 6, 16149 Genoa, Italy \\ ${ }^{3}$ E-mail: giuliano.greco@ge.ismar.cnr.it
}

Key words: antifouling, crustaceans, epibiosis, green crab, moulting process, SEM

\begin{abstract}
During its life cycle Carcinus maenas (Decapoda, Portunidae) goes through several phases of the moulting process (ecdysis) which allow it to grow despite having a rigid, non-living outer surface. As an individual approaches ecdysis, the exoskeletal calcium is solubilized (decalcification) from the shell and transferred through the integumentary epithelium to the blood, where much of it is transported to cells, tissues and organs of temporary storage where it is later mobilized for deposition into the new exoskeleton. We hypothesised that the decalcification process caused deterioration of the features and structures (e.g. tubercles and setae) characterizing the crab carapace, but that this can be reversed by moulting. We also tested whether wear and tear caused by abiotic and biotic influences between moults might also cause surface deterioration. Any such deterioration would be detrimental to C. maenas. For example, compromise of the function of these structures could influence the settlement rate of epibionts on the crab surface as well as interfering with sensory and regulatory physiology. In this study, animals characterized as intermoult, premoult and postmoult crabs, were selected and their carapace surfaces analysed to evaluate the relationship between deterioration and moulting stage. Data showed that the outer surfaces of Carcinus maenas were subject to deterioration of their fine microtopographies throughout their life, probably influencing epibiotic settlement. Furthermore, the moulting process, already recognized as crucial for growth and removal of fouling epibionts, also proved to be necessary for the periodic restoration of surface microtopography. These findings, besides providing new insights into details of the crab life cycle, indicate a likely antifouling property for carapace microtopography in C. maenas.
\end{abstract}

\section{Contents}

Introduction 167

Material and methods ............................................................ 169

Statistical analysis .............................................................. 169

Results .............................................................................. 171

Carapace deterioration before and after moult ............ 171

Carapace deterioration after different intermoult phase durations
Discussion and conclusion ........................................................ 172

Acknowledgements ...................................................................... 173

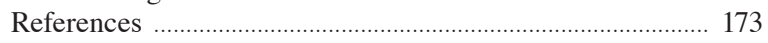

\section{Introduction}

Ecdysis (moulting), the process by which the inelastic cuticle is shed and renewed, is a defining feature of the life history of arthropods, including crustaceans. During moulting, the entire outer surface (including that of gills, eyes, grooming structures and sensilla) is replaced. Normally, moulting is associated with growth, which is saltatory rather than continuous in these invertebrates, and also with regeneration of lost appendages. However, moulting is also known to be important in removing fouling organisms (epibionts) in aquatic crustaceans (e.g. Bauer, 2002). Less well understood are the effects of wear and tear between moults. In this study we address this deficiency using a convenient model.

Carcinus maenas (Linnaeus, 1758) (Decapoda, Portunidae) is a widely distributed epibenthic crab that inhabits hard and soft intertidal shallow habitats of the European coast and estuaries. During its life cycle it goes through several phases of the moulting process. This can be divided into five main stages (A, B, C, D, E) from newly moulted (A) to ecdysis (E), passing through several postmoult $(\mathrm{B}, \mathrm{C})$ and premoult stages (D); each stage can be further divided into several substages (Passano, 1960). Frequency of moulting is influenced by factors closely related to the metabolism of the crab, as well as by environmental conditions (Hartnoll, 2001; Styrishave, 2004). C. maenas, after several moults, can reach the $\mathrm{C}_{4} \mathrm{~T}$ stage of the moulting cycle. This is characterized by cessation of moulting (anecdysis) (Hartnoll, 1982). This stage generally occurs in 
crustaceans that reach a large size, and represents a shift from a growing to a reproductive life strategy (Styrishave, 2004); crabs in anecdysis are generally characterized by a dark red colour. Carcinus maenas can be found in two different colour morphotypes (green and red) depending on the intermoult phase duration (Reid et al., 1997). This change in colour is due to the photodegradation of the integumental pigment astaxanthin that occurs during the intermoult stage (Jencks and Buten, 1964; Lee, 1977) .

Crabs spend most of their time in intermoult; during this period they feed, reproduce and carry out dayto-day activities. As an individual approaches premoult, the exoskeletal calcium is solubilized (decalcification) from the shell and transferred through the integumentary epithelium to the blood, where much of it is transported to cells, tissues and organs of temporary storage where it is later mobilized for deposition into the new exoskeleton (Ahearn et al., 2004). Decalcification is one of the main events of the premoult stage (Roer and Dillaman, 1984).

Even though the moulting process has been studied by many research groups in the last half century (Drach and Tchernigovtzeff, 1967; Engel and Brouwer, 1987, 1991; McGaw et al., 1992; Groeneveld and Branch, 2001; Godbout et al., 2002; Styrishave, 2004; Dam et al., 2006; Ziegler et al., 2007), no studies of the external morphological changes that characterize the crab outer surface during the moult cycle (including any degradation of the carapace structures) have been performed.

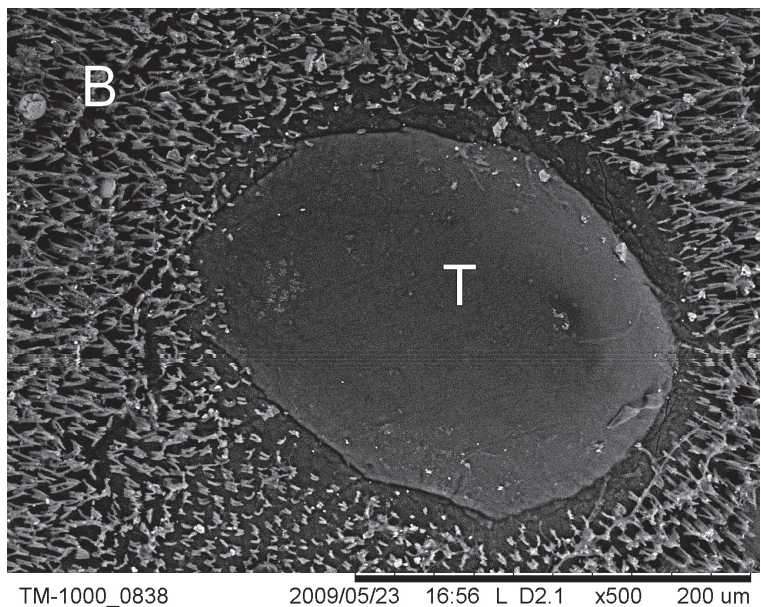

Fig. 1. SEM image of intact Carcinus maenas carapace 2 weeks after moult showing the two main structures characterizing its surface: tubercles (T) and bristles (B); scale bar $=200 \mu \mathrm{m}$, magnification: $500 \times$.
Any deterioration of tubercles and bristles, the main structures occurring on the crab carapace (Bottari et al., 2003), under the influence of biotic and abiotic factors and not simply the decalcification process, could be detrimental for $C$. maenas. For example, compromise of the function of these structures could influence the settlement rate of epibionts on the crab surface, since the topography and features of the carapace are known to have an important role in preventing the settlement of organisms as reported for the crab Cancer pagurus (Bers and Wahl, 2004) and for other marine organisms by several authors (Dyrynda, 1986; Baum et al., 2002; Scardino and de Nys, 2004; Guenther and De Nys, 2007; Ralston and Swain, 2009; Scardino et al., 2009; Bixler and Bhushan, 2012). The settlement of epibionts is one of the major issues influencing the life of $C$. maenas. In some crab species, including spider crabs of the genus Maja, epibionts have a beneficial role (Parapar et al., 1997; Fernandez et al., 1998), since the crabs take advantage of the settlement of epibionts on their surfaces to camouflage themselves from predators. However, in C. maenas, as in many other active and predatory species, the settlement of epibionts on the crab outer surface is a serious problem leading to several harmful effects. These include: increases in weight, drag and friction, mechanical and chemical damage, degraded gas exchange, decreased excretory capability and reduced sensory performance. These various effects, in turn, cause an enhanced susceptibility to predation and a weakened

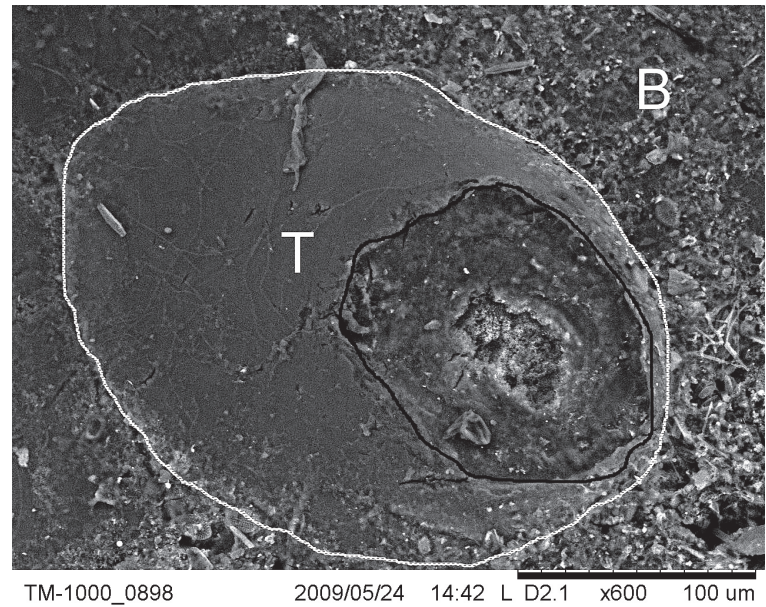

Fig. 2. SEM image of a damaged tubercle of Carcinus maenas; the black line indicates the projected area of the exposed exocuticle, the white line indicates the overall projected area of the tubercle; scale bar $=100 \mu \mathrm{m}$, magnification: $600 \times$. Note damaged bristles (B) surrounding tubercle (T). 
competitive ability (e.g. to capture food items) (McKenzie and Grigolava, 1996; Wahl, 1997, 2008). In addition to effects on epibiont colonisation, any deterioration of the outer surface likely affects the integrity of the numerous sensors that are mounted on hairs and bristles (e.g. chemosensory funnel canal organs of leg sensilla; Schmidt and Gnatzy, 1989).

Our study tested the hypotheses that: 1) the external surface of the exoskeleton deteriorates between moults, 2) deterioration is caused by the decalcification process shortly before moult, 3) deterioration is caused by a process of wear and tear during the intermoult process, so will be more pronounced in crabs that have not moulted for a long time, and 4) the moulting process reverses surface deterioration. Hypotheses 2) and 3) are not mutually exclusive, so a subsidiary aim was to determine the relative importance of decalcification and intermoult duration to any surface deterioration.

To conduct these tests, crabs in the late premoult stage ('peelers') were used to study carapace deterioration pre moult and any restoration post moult. Also, crabs characterized by different intermoult stage durations were selected on a colour basis and their carapace surfaces were analysed to evaluate the relationship between deterioration and intermoult phase duration.

\section{Material and methods}

Crabs were collected at Monkstown (51 50'59.06”N, $8^{\circ} 19^{\prime} 51.55$ 'W, Cork Harbour, Cork, Ireland) by use of baited traps and divided into three groups: peelers, green and red crabs. Peelers (crabs near to the moulting process) were kept in individual aerated 21 tanks with natural seawater renewed every day at $20^{\circ} \mathrm{C}$ until moulting, which usually occurred in 2-7 days under these conditions. Green and red crabs were kept in communal 401 tanks (10 animals per tank) in a recirculating system with natural seawater at environmental temperature (about $15^{\circ} \mathrm{C}$ ). Green and red crabs were fed once per week with fish and mussels.

Five peeler crabs were used to evaluate the pre/post moult change in carapace morphological features. The analysis was carried out on small-sized individuals (carapace width about $30 \mathrm{~mm}$ ) that are likely to moult several times during the year, since moulting frequency decreases with the increasing size (Crothers, 1968; McGaw et al., 1992; Abello et al., 1994; Styrishave, 2004). The choice of small crabs, in this first part of the study, allowed minimization of the potential ef- fects of time on the crabs' outer surfaces. After the peelers had moulted, the exuviae (moulted integuments) were collected and the newly-moulted soft crabs were left in sea water for 2 weeks before analysis to allow sufficient shell hardening. They were killed with clove oil (Gardner, 1997). Pieces of carapace (from exuviae and 2-weeks post moult) $1 \times 1 \mathrm{~cm}$ in size were removed from the epibranchial area; each carapace fragment was twice rinsed in distilled water and placed in $70 \%$ ethanol prior to observation with a tabletop scanning electron microscope HITACHI TM1000 (magnification: 500-800x); this sample preparation method and the lack of a sputtered metal coating prevented observation of the soft fraction present on crab carapace (i.e. bacteria, protozoans, etc.). Carcinus maenas carapace structure is characterized by two main features: bristles and tubercles (Bottari et al., 2003) (Fig. 1). Images of 10 randomly-selected tubercles per carapace fragment were taken and analysed using the software package ImageJ. Deterioration was quantified by establishing the percentage damage of each tubercle, calculated as the percentage of the overall projected area of the tubercle that consisted of exposed exocuticle (projected area of the exposed exocuticle / projected area of the tubercle $\times 100$ ) (Fig. 2);

To evaluate the time-dependent deterioration of the carapace surface, 5 green crabs, 5 red crabs and 5 fouled red crabs (i.e. red crabs in late postmoult or anecdysis stage with epibionts, predominantly barnacles and polychaetes with calcareous tubes, covering more than $20 \%$ of the carapace) were used. All of the selected crabs were intact, with no missing appendages or evident physical damage. Green, red and fouled red crab groups (carapace width $40-70 \mathrm{~mm}$ ) represented three different intermoult phase durations: short-medium (green crabs); medium-long (red crabs) and long-very long (fouled red crabs). Crab colour was determined using the Munsell Color system (Munsell, 1954; Davenport and Thorsteinsson, 1989). Specimens with the endopodites of third maxillipeds of a hue from $5.0 \mathrm{Y}$ to $10.0 \mathrm{GY}$ were considered green while those of hue 5.0 R to 10.0 YR were considered red. Green, red and fouled red crabs were treated in similar fashion to the peeler crab group and the deterioration percentage of the carapace features was evaluated and analysed as described above.

\section{Statistical analysis}

Statistical analysis of the data was carried out using SPSS (SPSS Inc, Chertsey, UK) statistical software. 

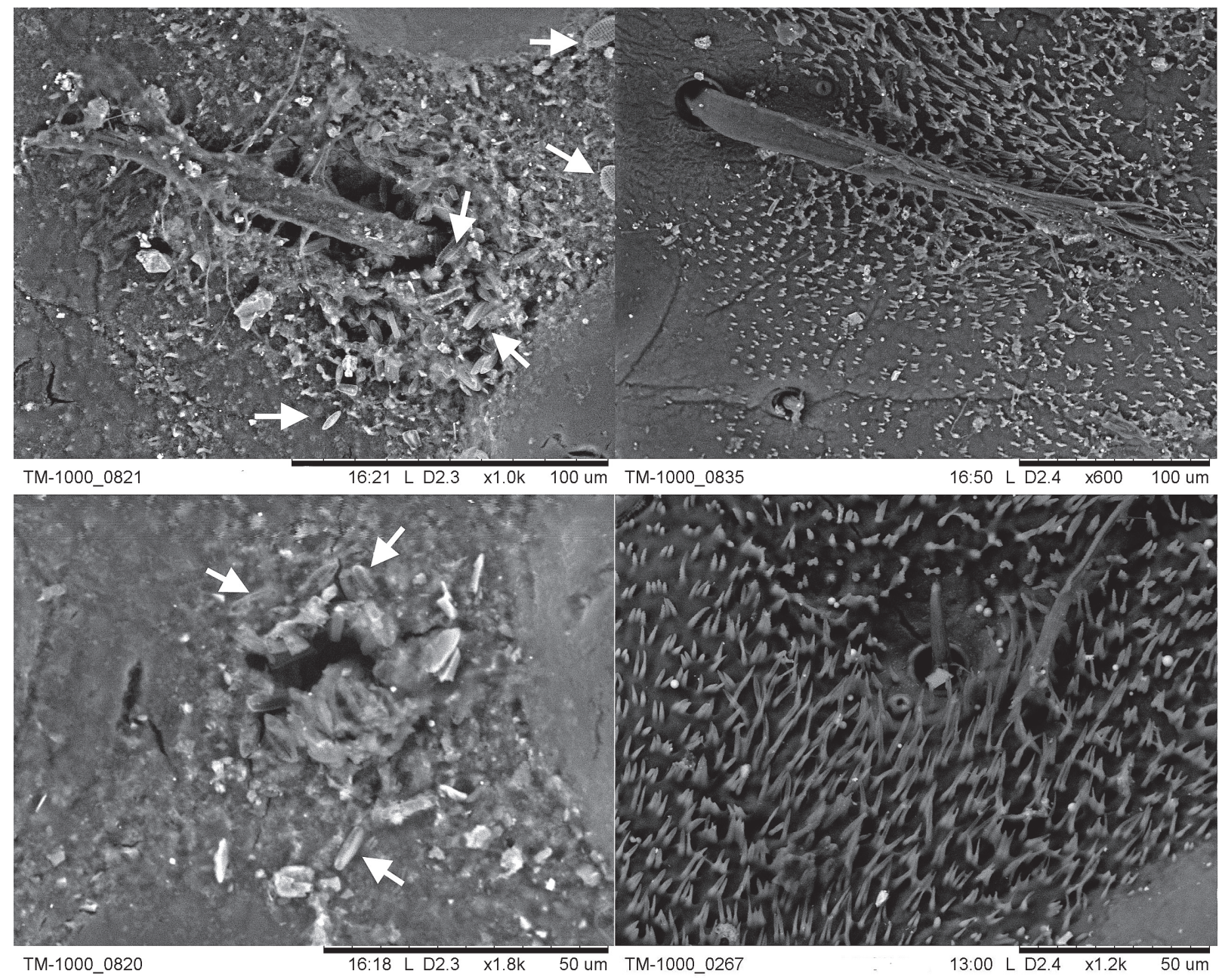

Fig. 3. SEM images of different kind of bristles on the carapace of Carcinus maenas before (left) and after (right) the moulting process. Arrows indicate diatoms on the crab carapace surface. For scale bar and magnification see single images bottom bar.

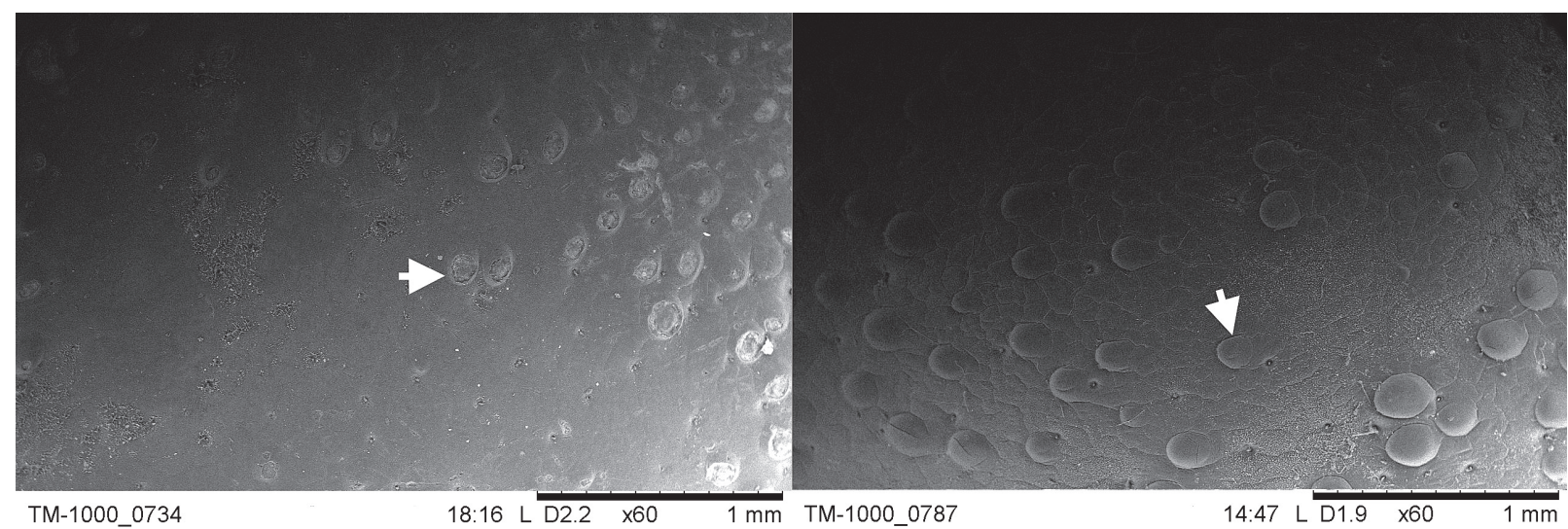

Fig. 4. SEM images of crab carapace fragments of Carcinus maenas before (left) and after (right) the moulting process. Arrows indicate a damaged (left) and an intact (right) tubercle on the crab carapace surface. For scale bar and magnification see single images bottom bar. 
Table 1. Levels of carapace deterioration (\%) before and after moult in green 'peeler' specimens of Carcinus maenas.

\begin{tabular}{lll}
\hline $\begin{array}{l}\text { Specimen } \\
\text { number }\end{array}$ & $\begin{array}{l}\text { before moult } \\
\text { (deterioration\%) }\end{array}$ & $\begin{array}{l}\text { after moult } \\
\text { (deterioration\%) }\end{array}$ \\
\hline 1 & 18.4 & 0.09 \\
2 & 37.1 & 0.19 \\
3 & 17.7 & 0.15 \\
4 & 3.2 & 0.02 \\
5 & 21.7 & 0.03 \\
\hline Mean \pm SD & $19.6 \pm 5.40$ & $0.09 \pm 0.03$ \\
\hline
\end{tabular}

Statistical significance was assumed at $\mathrm{p}<0.05$. Carapace deterioration data before and after moult were arcsin transformed and analysed by paired $\mathrm{T}$ test. The difference among damage percentages in the three life

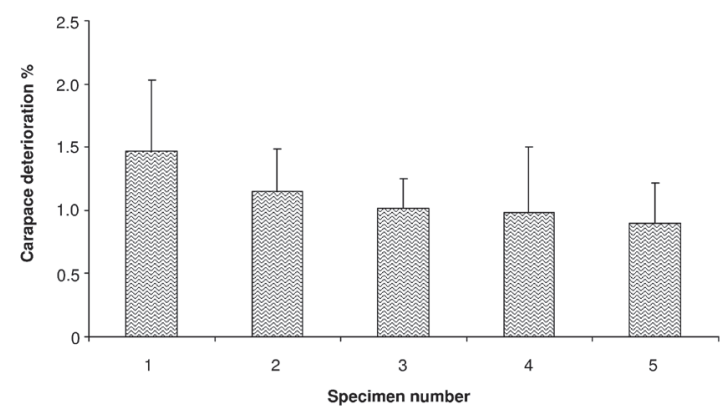

Fig. 5. Levels of carapace deterioration recorded in green specimens (short - medium intermoult phase duration) of the shore crab Carcinus maenas (Mean $\pm \mathrm{SE}, \mathrm{n}=10$ ).

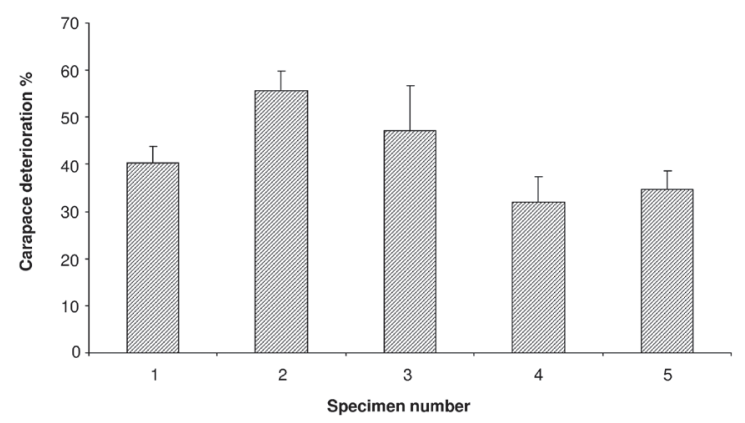

Fig. 7. Levels of carapace deterioration recorded in red fouled specimens (long - very long intermoult phase duration) of the shore crab Carcinus maenas (Mean $\pm \mathrm{SE}, \mathrm{n}=10$ ). stages considered was evaluated by a one way ANOVA test, followed by a Least Significant Difference post hoc test (LSD). Data were arcsin square root transformed prior to analysis to achieve normality.

\section{Results \\ Carapace deterioration before and after moult}

Five carapace fragments belonging to moults (exuviae) and 5 belonging to the corresponding newly moulted crabs were analysed. Means of the percentage of carapace damage of 10 random tubercles of each crab before and after moult are shown in Table 1. Considering single crab specimens, the results show similar trends in pre-moult and post moult carapace damage percentage data: the specimens showing higher levels of dete-

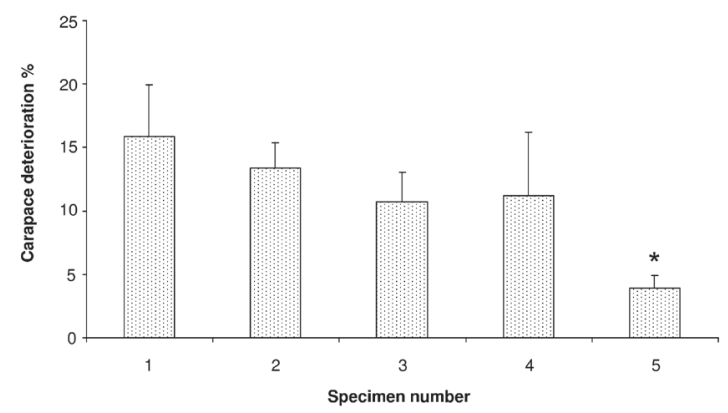

Fig. 6. Levels of carapace deterioration recorded in red specimens (medium - long intermoult phase duration) of the shore crab Carcinus maenas (Mean $\pm \mathrm{SE}, \mathrm{n}=10$ ). * = significantly different from specimen 1, 2, 3; one way ANOVA, LSD post-hoc comparison $(\mathrm{p}<0.05)$

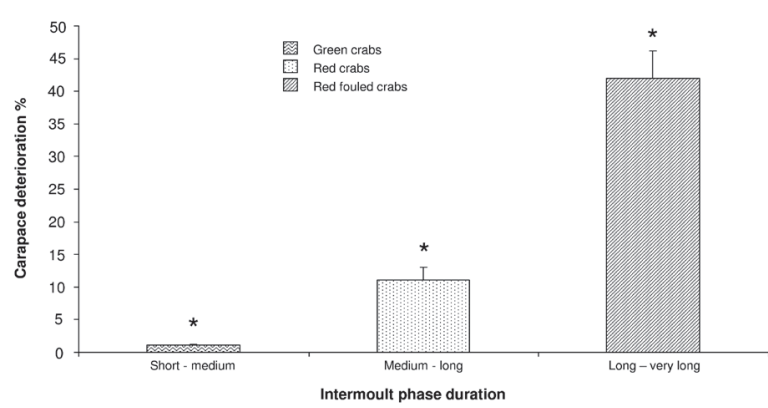

Fig. 8. Comparison of overall levels of carapace deterioration in the three studied categories of specimens of Carcinus maenas. Green crabs were of short-medium intermoult duration; red crabs of medium-long intermoult duration and red fouled crabs were of long-very long intermoult duration (Mean \pm SE, $\mathrm{n}=5) . *=$ highly significant difference from the other categories $(\mathrm{p}<0.001$, one way ANOVA). 


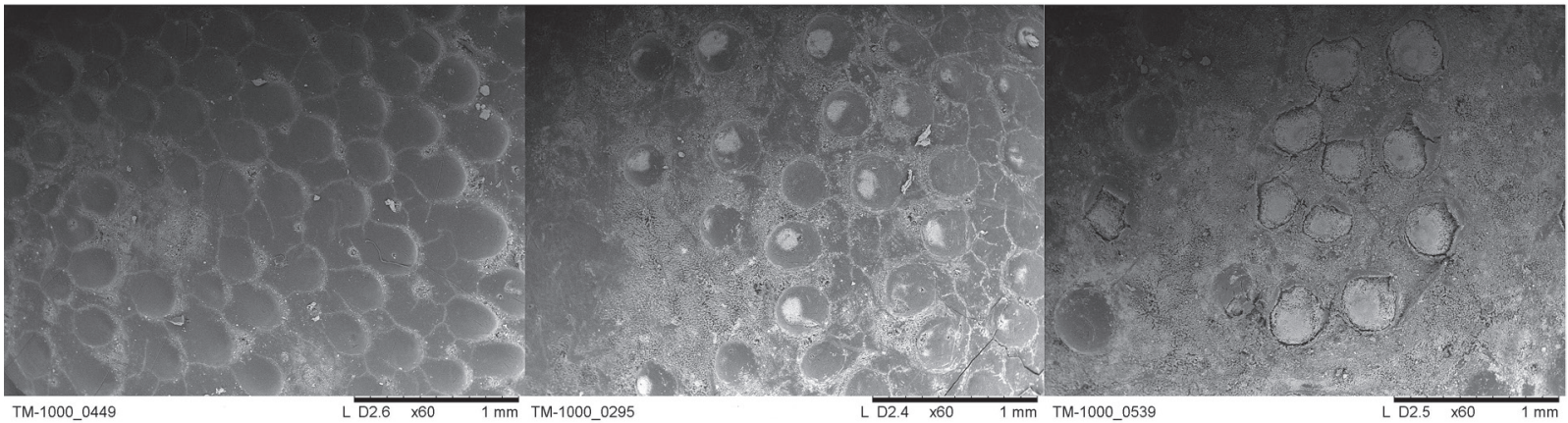

Fig. 9. SEM images of crab carapace fragments of a green (left), red (center) and red fouled (right) specimens (Carcinus maenas). Note the different accumulation of debris and deterioration level on the carapace surfaces. Scale bar $=1 \mathrm{~mm}$, magnification: $60 \times$.

rioration in the pre-moult stage also exhibited higher levels of deterioration in the post moult stage. However, overall, carapace damage before moult (mean 19.6\%), was much greater (paired samples $\mathrm{T}$-test $\mathrm{p}<0.005$ ), by an average factor of about 218 , than the post-moult level of deterioration (mean $0.09 \%$ ). Clearly, surface deterioration is high before moult and is almost completely reversed by moulting, confirming hypotheses 1 and 4 (Figs 3-4).

\section{Carapace deterioration after different intermoult phase durations}

The amounts of carapace damage exhibited by crabs characterized by different intermoult phase durations are shown in Figs 5-7. Within groups, almost all specimens displayed similar deterioration values, showing that deterioration is consistent in groups made up of crabs of the same size and colour range. No statistically significant differences were found amongst the amounts of carapace damage among specimens belonging to a single group with the exception of specimen number 5 of the red crabs group that was significantly different from specimens 1,2 and 3 (one way ANOVA followed by LSD post-hoc comparison; $\mathrm{F}_{(4,45)}$ $=0.26 ; \mathrm{p}=0.02 ; \mathrm{p}<0.05$ ) (Fig. 6). On the other hand, overall the results revealed a dramatic difference in level of carapace damage percentage between groups (Fig. 8) (one way ANOVA followed by LSD post-hoc comparison $\mathrm{F}_{(4,20)}=40.50 ; \mathrm{p}=2.5510^{-9}: \mathrm{p}<<0.001$ ). The amount of carapace damage is clearly proportional to the length of the intermoult phase duration. Crabs characterized by a short medium intermoult period (green crabs) displayed a mean deterioration value of less than $2 \%(1.1 \pm 0.10 \%)$, while crabs in the mediumlong intermoult period (red crabs) showed values of deterioration around 10\% (11.0 $\pm 1.99 \%)$ and crabs characterized by a long - very long intermoult phase duration (fouled red crabs, probably in anecdysis) had a carapace deterioration percentage above $40 \%$ (41.9 \pm $4.30 \%)$.

Taken together these data confirm hypothesis 3 ; the longer the period between moults, the more the carapace surface deteriorates (Fig. 9).

Given the data for relatively small green peeler crabs immediately before moult shown in Table 1 (mean 19.6\% deterioration), plus the data for intermoult green crabs (Fig. 5; mean 1.1\%), it is evident that the decalcification process immediately prior to moult causes the carapace surface structure to deteriorate considerably (by a factor of around 18); this confirms hypothesis 2 .

\section{Discussion and conclusion}

This study shows clearly that carapace tubercles and bristles deteriorate as a result of wear and tear, with red crabs showing more deterioration than green ones, while older fouled red crabs (that have probably ceased moulting) show even more damage. As hypothesised, moulting restores the outer surface to pristine condition, so it is evident that moulting has a repair function in crabs, as well as being necessary for growth, regeneration of lost appendages and antifouling.

However, the results also showed that deterioration to a relatively high level (much higher than in intermoult crabs) takes place immediately before moult in green crabs. This novel morphological observation indicates that deterioration beyond that caused by wear and tear is associated with the moulting process itself, during the constitution of the new carapace when exoskeletal 
calcium is solubilised (decalcification) (Ahearn et al., 2004). Whether this moult-associated deterioration is directly caused by decalcification, or because the decalcified carapace is particularly vulnerable to wear is not known. However, the moulting process almost completely reverses this short-term deterioration.

Our findings raise some other issues. The green intermoult crabs showed no macroscopic fouling and had very low levels of tubercle and bristle deterioration (mean 1.1\%). Red crabs moult less often and so have more time for wear and tear to take place (and more time for epibionts to settle), but the surface can still be renewed at intervals. In our study such crabs showed negligible levels of fouling, but the mean surface deterioration level was $11 \%$. The fouled red group of crabs were in the terminal ecdysis stage (anecdysis) during which they stop moulting. These crabs are characterized by a dark red colour (Dam et al., 2006) and by a thicker, harder and more calcified carapace. At this stage moulting never takes place. Fouled red crabs in this study showed a carapace deterioration $>40 \%$, far higher than in red crabs without fouling. This suggests that deterioration of the carapace beyond a threshold value can lead to an increase in epibiont settlement. Microalgae and macroinvertebrate larvae prefer to settle in areas slightly larger than themselves for maximum protection and surface area contact with the substrate. Fewer attachment points between the micro-organisms and substrate translate into lower bioadhesive strength (Scardino et al., 2008); the tubercles and bristles on the surface of $C$. maenas could play an important role in the prevention of epibiont settlement as reported for other crab species (Bers and Wahl, 2004), thereby reducing the number of available attachment points on the crab carapace surface. Damage/loss of these structures may facilitate epibiont colonization, since complex surface microtopography is known to function as a natural antifouling mechanism (Baum et al., 2002; Bers and Wahl, 2004; Bers et al., 2006; Ralston and Swain, 2009; Scardino et al., 2009; Bixler and Bhushan, 2012) and it is also known that the deterioration of topographical features on a surface can reduce this effect (Scardino and de Nys, 2004), leading to all of the negative effects associated with epibiosis (McKenzie and Grigolava, 1996; Wahl, 1997, 2008).

It is also well known that red morphs of $C$. maenas have significantly narrower physiological tolerances than green morphs (Reid and Aldrich, 1989; McGaw and Naylor, 1992a,b) that leads to red animals being found in subtidal areas rather than the intertidal and estuarine habitats where the green morphs are found.
Exchange processes take place at the surfaces of crustaceans, so it is possible that the higher levels of surface deterioration shown by the red morph, if also characteristic of permeable parts of the integument (especially the gills), may impact upon respiratory and osmoregulatory processes.

In conclusion, it can be seen that the outer surfaces of C. maenas are subject to deterioration of their fine microtopography throughout their life. This deterioration partly results from external abrasive abiotic/biotic factors, but is also caused by the decalcification that precedes moulting. It is also probable, even if not supported by direct evidence, that surface deterioration promotes epibiotic settlement in crabs that have moulted for the last time. This finding suggests a possible antifouling property of carapace microtopography in C. maenas that may represent a source of bioinspiration for human antifouling technologies as already suggested in a previous work (Greco et al., 2013). It is also evident that the moulting process, already recognized as crucial for growth and removal of fouling epibionts, is also necessary for the restoration of surface microtopography; it may also play a role in sustaining physiological tolerances.

\section{Acknowledgements}

We acknowledge the Irish Research Council for Science, Engineering and Technology (IRCSET) for the financial support to this project and the anonymous reviewers for their valuable comments and suggestions to improve the quality of the paper.

\section{References}

Abello P, Warman CG, Reid DG, Naylor E. 1994. Chela loss in the shore crab Carcinus maenas (Crustacea, Brachyura) and its effect on mating success. Marine Biology 121: 247-252.

Ahearn GA, Mandal PK, Mandal A. 2004. Calcium regulation in crustaceans during the molt cycle: a review and update. Comparative Biochemistry and Physiology - Part A: Molecular and Integrative Physiology 137: 247-257.

Ahl JSB, Laufer H, Ahl AJ, Takac P. 1996. Exoskeletal abrasion as an indicator of reproductive readiness in the spider crab Libinia emarginata. Journal of Crustacean Biology 16: 443-447.

Bauer RT. 2002. The ineffectiveness of grooming in prevention of body fouling in the red swamp crayfish, Procambarus clarkii. Aquaculture 208: 39-49.

Baum C, Simon F, Meyer W, Fleischer LG, Siebers D, Kacza J, Seeger J. 2002. Surface properties of the skin of the pilot whale Globicephala melas., 11th International Congress on Marine Corrosion and Fouling. Taylor and Francis Ltd, San Diego, California, 181-186. 
Bers AV, Wahl M. 2004. The influence of natural surface microtopographies on fouling. Biofouling 20: 43-51.

Bers AV, Prendergast GS, Zurn CM, Hansson L, Head RM, Thomason JC. 2006. A comparative study of the anti-settlement properties of mytilid shells. Biology Letters 2: 88-91.

Bixler GD, Bhushan B. 2012. Biofouling: lessons from nature. Philosophical Transaction of the Royal Society A 370: 23812417.

Bottari T, Marino E, Spano N. 2003. Scanning electron microscopy of the carapace of some Mediterranean crab species. Journal of Submicroscopic Cytology and Pathology 35: 431-437.

Crothers JH. 1968. The biology of the shore crab Carcinus maenas (L.): II. The life of the adult crab. Field Studies 2: 579-614.

Dam E, Styrishave B, Rewitz KF, Andersen O. 2006. Intermoult duration affects the susceptibility of shore crabs Carcinus maenas (L.) to pyrene and their ability to metabolise it. Aquatic Toxicology 8: 290-297.

Davenport J, Thorsteinsson V. 1989. Observations on the colours of the lumpsuckers Cyclopterus lumpus L. Journal of Fish Biology 35: 829-838.

Drach P, Tchernigovtzeff C. 1967. Method for determining intermoulting stages and its general application to crustacea. Vie Et Milieu Serie a-Biologie Marine 18: 595-607.

Dyrynda PEJ. 1986. Defensive Strategies of Modular Organisms. Philosophical Transactions of the Royal Society of London. B, Biological Sciences 313: 227-243.

Engel DV, Brouwer M. 1987. Metal regulation and molting in the blue crab, Callinectes sapidus: metallothionein function in metal metabolism. The Biological Bulletin 172: 237-249.

Engel DV, Brouwer M. 1991. Short-Term Metallothionein and Copper Changes in Blue Crabs at Ecdysis. The Biological Bulletin 180: 447-452.

Fernandez L, Parapar J, Gonzalez-Gurriaran E, Muino R. 1998. Epibiosis and ornamental cover patterns of the spider crab Maja squinado on the Galician coast, northwestern Spain: Influence of behavioral and ecological characteristics of the host. Journal of Crustacean Biology 18: 728-737.

Gardner C. 1997. Options for humanely immobilizing and killing crabs. Journal of Shellfish Research 16: 219-224.

Godbout G, Dutil JD, Hardy D, Munro J. 2002. Growth and condition of post-moult male snow crab (Chionoecetes opilio) in the laboratory. Aquaculture 206: 323-340.

Greco G, Svaldo Lanero T, Torrassa S, Young R, Vassalli M, Cavaliere A, Rolandi R, Pelucchi E, Faimali M, Davenport J. 2013. Microtopography of the eye surface of the crab Carcinus maenas: an atomic force microscope study suggesting a possible antifouling potential. Journal of the Royal Society Interface 10: 20130122.

Groeneveld JC, Branch GM. 2001. Development of a pleopod index to assess the moulting season of rock lobster, Palinurus gilchristi (Decapoda, Palinuridae) off south africa, Crustaceana 74: 1083-1100.

Guenther J, De Nys R. 2007. Surface microtopographies of tropical sea stars: lack of an efficient physical defence mechanism against fouling. Biofouling 23: 419-429.

Hartnoll RG. 1982. Growth. Pp. 111-196 in: Bliss DE, Abele LG, eds, The Biology of Crustacea, 2, Embryology, Morphology and Genetics. New York: Academic Press.

Hartnoll RG. 2001. Growth in Crustacea - twenty years on. Hydrobiologia 449: 111-122.
Hebert M, Benhalima K, Miron G, Moriyasu M. 2002. Moulting and growth of male snow crab, Chionoecetes opilio (O. Fabricius, 1788) (Decapoda, Majidae), in the southern Gulf of St. Lawrence. Crustaceana 75: 671-702.

Jencks WP, Buten B. 1964. The denaturation of crustacyanin. Archives of Biochemistry and Biophysics 107: 511-520.

Lee WE. 1977. Carotenoproteins in Animal Coloration. Pp 395. Hutchinson and Ross, Stroudsburg.

Lucu C. 1994. Calcium transport across isolated gill epithelium of Carcinus. Journal of Experimental Zoology 268: 339346.

McGaw IJ, Kaiser MJ, Naylor E, Hughes RN. 1992. Intraspecific morphological variation related to the moult-cycle in color forms of the shore crab Carcinus maenas. Journal of Zoology 228: 351-359.

McGaw IJ, Naylor E. 1992a. Salinity preference of the shore crab Carcinus maenas in relation to coloration during intermoult and to prior acclimation. Journal of experimental marine Biology and Ecology 155: 145-159.

McGaw IJ, Naylor E. 1992b. Distribution and rhythmic locomotor patterns of estuarine and open-shore populations of Carcinus maenas. Journal of the Marine Biological Association of the United Kingdom 72: 599-609.

McKenzie JD, Grigolava IV. 1996. The echinoderm surface and its role in preventing microfouling. Biofouling 10: 261-272.

Munsell AH. 1954. A color notation. Pp 67. Munsell Color. Munsell Color Company Inc., Baltimore.

Parapar J, Fernandez L, Gonzalez-Gurriaran E, Muino R. 1997. Epibiosis and masking material in the spider crab Maja squinado (Decapoda : Majidae) in the Ria de Arousa (Galicia, NW Spain). Cahiers de Biologie Marine 38: 221-234.

Passano LM. 1960. Moulting and its control. Pp. 473-536 in: Waterman TH, ed., The Physiology of Crustacea. New York: Academic Press.

Ralston E, Swain G. 2009. Bioinspiration-the solution for biofouling control? Bioinspiration and Biomimetics 4: 1-9.

Reid DG, Abelló P, Kaiser MJ, Warman CG. 1997. Carapace colour, inter-moult duration and the behavioural and physiological ecology of the shore crab Carcinus maenas. Estuarine, Coastal and Shelf Science 44: 203-211.

Reid DG, Aldrich JC. 1989. Variations in response to environmental hypoxia of different colour forms of the shore crab, Carcinus maenas. Comparative Biochemistry and Physiology A 92: 535-539.

Roer R, Dillaman R. 1984. The structure and calcification of the crustacean cuticle. American Zoologist 24: 893-909.

Sampedro MP, Gonzalez-Gurriaran E, Freire J. 2003. Moult cycle and growth of Maja squinado (Decapoda : Majidae) in coastal habitats of Galicia, north-west Spain. Journal of the Marine Biological Association of the United Kingdom 83: 995-1005.

Scardino AJ, de Nys R. 2004. Fouling deterrence on the bivalve shell Mytilus galloprovincialis: A physical phenomenon? Biofouling 20: 249-257.

Scardino AJ, Guenter J, de Nys R. 2008. Attachment point theory revisited: the fouling response to a microtextured matrix. Biofouling 24: 45-53.

Scardino AJ, Hudleston D, Peng Z, Paul NA, de Nys R. 2009. Biomimetic characterisation of key surface parameters for the development of fouling resistant materials. Biofouling 25: 83-93. 
Schmidt M, Gnatzy W. 1989. Specificity and response characteristics of gustatory sensilla (funnel-canal organs) on the dactyls of the shore crab, Carcinus maenas (Crustacea, Decapoda). Journal of Comparative Physiology A 166: 227242.

Styrishave B, Rewitz K, Andersen O. 2004. Frequency of moulting by shore crabs Carcinus maenas (L.) changes their colour and their success in mating and physiological performance. Journal of Experimental Marine Biology and Ecology 313: 317-336.

Wahl M. 1997. Living attached: Aufwuchs, fouling, epibiosis. Pp 31-83 in: Nogabushanam R, Thompson M, eds, Fouling Organisms of the Indian Ocean: Biology and Control Technology. New Dehli: Oxford and IBH Publishing Company.
Wahl M. 2008. Ecological lever and interface ecology: epibiosis modulates the interactions between host and environment. Biofouling 24: 427-438.

Ziegler A, Hagedorn M, Ahearn GA, Carefoot TH. 2007. Calcium translocations during the moulting cycle of the semiterrestrial isopod Ligia hawaiiensis (Oniscidea, Crustacea). Journal of Comparative Physiology B-Biochemical Systemic and Environmental Physiology 177: 99-108.

Received: 15 July 2013

Revised and accepted: 18 April 2014

Published online: 6 June 2014

Editor: R. Vonk 